\title{
Organo-gallium and indium complexes with dithiolate and oxo ligands: Synthesis, structures and applications
}

\author{
VIMAL K JAIN*, AMEY WADAWALE, NISHA P KUSHWAH and MANOJ K PAL \\ Chemistry Division, Bhabha Atomic Research Centre, Mumbai, 400 085, India \\ e-mail: jainvk@barc.gov.in
}

\begin{abstract}
The chemistry of organo-gallium and indium complexes with dithiolate and internally functionalised oxo ligands has been explored. With 1,1-dithiolate ligands both classical and organometallic complexes of gallium and indium, $\left[\mathrm{M}\left(\mathrm{S}^{\cap} \mathrm{S}\right)_{3}\right],\left[\mathrm{RM}\left(\mathrm{S}^{\cap} \mathrm{S}\right)_{2}\right]$ and $\left[\mathrm{R}_{2} \mathrm{M}\left(\mathrm{S}^{\cap} \mathrm{S}\right)\right]$ (where $\mathrm{R}=\mathrm{Me}$ or Et; $\mathrm{M}=\mathrm{Ga}$ or In; $\mathrm{S}^{\cap} \mathrm{S}=$ $\mathrm{RCS}_{2}, \mathrm{ROCS}_{2}, \mathrm{R}_{2} \mathrm{NCS}_{2}$ and $(\mathrm{RO})_{2} \mathrm{PS}_{2}$ ) have been isolated. Reactions of internally functionalised oxo ligands with $\mathrm{R}_{3} \mathrm{M} \cdot \mathrm{OEt}_{2}$ afforded diorganometal complexes $\left[\mathrm{R}_{2} \mathrm{ML}\right]_{\mathrm{n}}$. Molecular structures of several of these complexes have been established by single crystal X-ray diffraction analyses. Complexes derived from oxo ligands showed photoluminescence. They have been used as alkylating agents for $\mathrm{C}-\mathrm{C}$ coupling reactions of aryl bromides in the presence of $\mathrm{PdCl}_{2}\left(\mathrm{PPh}_{3}\right)_{2}$. Indium dithiolate complexes have been used as molecular precursors for the preparation of mono dispersed $\beta-\mathrm{In}_{2} \mathrm{~S}_{3}$ nanoparticles.
\end{abstract}

Keywords. Organo-gallium; organoindium; structures; $\operatorname{In}_{2} \mathrm{~S}_{3}$ nanoparticles; photoluminescence; $\mathrm{C}-\mathrm{C}$ coupling reactions.

\section{Introduction}

The chemistry of organo-gallium and indium compounds with group 16 ligands has been an active area of research for the last several years. ${ }^{1-3}$ The interest in these compounds stems from their rich structural diversity and their potential applications in catalysis ${ }^{4}$ and as molecular precursors for III-VI materials which have useful electronic and optical properties. ${ }^{5-7}$

The following aspects of gallium and indium compounds have attracted our attention while executing a project on high purity materials of group III and V elements required for advanced technologies.

(i) Molecular precursor for $\beta-\operatorname{In}_{2} \mathrm{~S}_{3}$ : Group III elements form numerous metal chalcogenides differing in composition and phases and find applications in opto-electronic and photovoltaic devices and catalysis. Among III-VI materials, $\beta$ - $\mathrm{In}_{2} \mathrm{~S}_{3}$ is a front-runner due to its desirable optical and acoustic properties and as a material of choice for passivating III-V films (e.g., $\mathrm{GaAs}$ ). In view to develop low temperature synthesis of $\beta$ - $\operatorname{In}_{2} \mathrm{~S}_{3}$ mono-dispersed nano-crystals, molecular precursor route, a versatile strategy in materials synthesis, has been explored.

(ii) $\mathrm{C}-\mathrm{C}$ coupling reactions: Carbon-carbon bond formation catalysed by palladium complexes is one

\footnotetext{
${ }^{*}$ For correspondence
}

of the most important reactions in organic synthesis. In $\mathrm{C}-\mathrm{C}$ coupling reactions of arylhalides, a variety of reagents are employed. Recently organoindium compounds have shown promising potential in $\mathrm{C}-\mathrm{C}$ coupling reactions. ${ }^{4}$

(iii) Photoluminescence properties of organogallium and indium compounds: Since the discovery of tris(8-hydroxyquinolinolato)aluminium(III) (AlQ) as organic electro-luminescent material, there has been growing interest to design and develop metal chelates of high luminous efficiency capable of emitting different colours for OLED (organic light emitting diode) applications. $^{8}$ Organometallic complexes derived from chelating ligands, such as substituted 8-hydroxyqunoline and azomethine linkages, are emerging as potential molecules for OLEDs.

In the above prospective we have explored the chemistry of gallium and indium compounds with 1,1dithiolate and oxo ligands in the last few years. Salient features of this investigation are described here.

\section{Results and discussion}

\subsection{1,1-Dithiolato-complexes}

Both classical and organometallic complexes of gallium and indium with 1,1-dithiolate ligands (dithiophosphate, dithiocarbamate, xanthate, dithiocarboxy- 
late) (scheme 1) have been synthesised employing reaction routes shown in scheme 2..$^{9-17}$ Redistribution reaction has been quite facile for the synthesis of organometallic derivatives, affording mono- and di-organometal derivatives in quantitative yields.

These complexes have been characterised by NMR $\left({ }^{1} \mathrm{H},{ }^{13} \mathrm{C},{ }^{31} \mathrm{P}\right.$, and $\left.{ }^{77} \mathrm{Ga}\right)$ and mass spectrometry and in some cases by single crystal X-ray crystallography. The ${ }^{1} \mathrm{H}$ and ${ }^{13} \mathrm{C}$ NMR chemical shifts were sensitive to the nature and the number of dithiolato ligands on the metal atom. The Me-M resonance in the ${ }^{1} \mathrm{H}$ and ${ }^{13} \mathrm{C}$ NMR spectra is progressively shifted downfield in the following order of substitution: $\mathrm{Me}_{3} \mathrm{M} \cdot \mathrm{OEt}_{2}>$ $\left[\mathrm{Me}_{2} \mathrm{M}\left(\mathrm{S}^{\cap} \mathrm{S}\right)\right]>\left[\mathrm{MeM}\left(\mathrm{S}^{\cap} \mathrm{S}\right)_{2}\right]$. The mass spectra of these complexes did not show molecular ion peaks nor any peak higher than the molecular ions. ${ }^{10,11,15,18}$ The tris complexes exhibited peaks attributable to ' $\left[\mathrm{M}\left(\mathrm{S}^{\cap} \mathrm{S}\right)_{2}\right]^{+}$' species, while the organoindium complexes showed peaks due to 'M-Me' fragments.

Structures, established by X-ray crystallography, consist of discrete monomeric molecules and adopt distorted geometries (scheme 3 ) due to restricted bite of dithio ligand. The tris complexes of gallium and indium are isostructural in nature acquiring a distorted octahedral configuration (figure 1). The In-S distances in tris complexes of indium varies between $2.554(4)$ and 2.652(5) $\AA$ with the progressively opening up, though slightly, of S-In-S angle in the following series: $\left[\mathrm{In}\left(\mathrm{S}_{2} \mathrm{Ctol}\right)_{3}\right]\left(68.73(4)^{\circ}\right) ;\left[\operatorname{In}\left\{\mathrm{S}_{2} \mathrm{C}\left(\mathrm{OPr}^{\mathrm{i}}\right)\right\}_{3}\right]$ (av 69.75 $)$; $\left[\operatorname{In}\left(\mathrm{S}_{2} \mathrm{CN}\left(\mathrm{CH}_{2}\right)_{4} \mathrm{NMe}\right)_{3}\right]\left(70.21(7)^{\circ}\right)$ and $\left[\operatorname{In}\left\{\mathrm{S}_{2} \mathrm{P}\left(\mathrm{OPr}^{\mathrm{i}}\right)_{2}\right\}_{3}\right] \quad\left(\right.$ av $\left.77.9^{\circ}\right) .{ }^{11,12,18,19}$ The complex $\left[\mathrm{MeGa}\left(\mathrm{S}_{2} \mathrm{Ctol}\right)_{2}\right]$ has two crystallographically independent molecules in the crystals, each have a five coordinated gallium atom. The geometry around gallium is
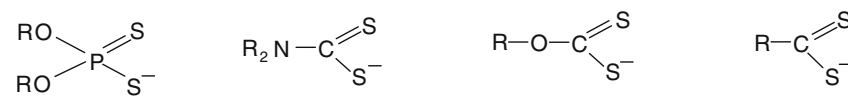

Scheme 1.

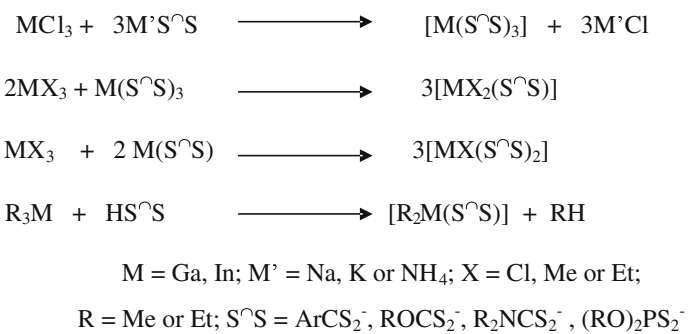

Scheme 2. intermediate between trigonal bipyramidal and square pyramidal configurations. ${ }^{17}$

\subsection{Thermal behaviour}

Thermal behaviour of indium complexes has been investigated by thermogravimetric analysis. ${ }^{12,16-18}$ Indium tris xanthates and tris dithiocarboxylates undergo a single-step decomposition with the formation of $\operatorname{In}_{2} \mathrm{~S}_{3}$ assessed by weight loss, EDAX and XRD pattern. Xanthates decomposed at much lower temperatures $\left(\sim 125^{\circ} \mathrm{C}\right)$ as compared to dithiocarboxylates $\left(\sim 190^{\circ} \mathrm{C}\right){ }^{16,18}$ Indium dithiocarbamates and $\left[\mathrm{Me}_{2} \operatorname{In}\left(\mathrm{S}_{2} \mathrm{Ctol}\right)\right]$, however showed a two-step decomposition ${ }^{12,17}$ leading to the formation of $\operatorname{In}_{2} \mathrm{~S}_{3}$.

Pyrolysis of dithiocarboxylate, xanthate and dithiocarbamate complexes has been carried out in a furnace and in boiling organic solvents (ethylene glycol, hexadecylamine). ${ }^{16-18}$ Thermolysis of $\left[\operatorname{In}\left(\mathrm{S}_{2} \mathrm{CPh}\right)_{3}\right]$ in $\mathrm{HDA}$ at $300^{\circ} \mathrm{C}$ yields $\beta-\mathrm{In}_{2} \mathrm{~S}_{3}$ with predominance of tetragonal phase (figure 2). Similarly a mixture of tetragonal and cubic $\beta-\operatorname{In}_{2} \mathrm{~S}_{3}$ is obtained when $\left[\mathrm{MeIn}\left(\mathrm{S}_{2} \mathrm{COPr}^{i}\right)_{2}\right]$ or $\left[\mathrm{Me}_{2} \operatorname{In}\left(\mathrm{S}_{2} \mathrm{COPr}{ }^{i}\right)\right]$ are heated at $450^{\circ} \mathrm{C}$ in a furnace under a flowing nitrogen. However, thermolysis of indium tris xanthates in refluxing ethylene glycol proceeds smoothly to afford yellow orange nano-crystals of $\mathrm{In}_{2} \mathrm{~S}_{3}$ which have spherical shape with the diameter varying in the range 19-30 nm (TEM studies).

\subsection{Diorgano-gallium and indium complexes with oxo ligands}

The reactions of triorganometal etherate with an appropriate internally functionalised anionic oxo ligand, viz. 2-(hydroxyalkyl)pyridines, N-heterocyclic carboxylic acids, 2-(2-hydroxyphenyl)oxazoline and 1-(2-hydroxyethyl)pyrazoles (scheme 4), in 1:1 molar ratio in benzene afforded readily dimeric diorganometal complexes containing central rectangular ' $\mathrm{M}_{2}(\mu-\mathrm{O})_{2}$ ' core (scheme 5). ${ }^{20-24}$ The mass spectra showed peaks higher than the formula weight suggesting their associated nature. Gallium and indium species can be identified readily from the characteristic isotopic pairs $\left({ }^{69} \mathrm{Ga} /{ }^{71} \mathrm{Ga} ;{ }^{113} \mathrm{In} /{ }^{115} \mathrm{In}\right)$. The spectra in general exhibit peaks due to $\mathrm{M}-\mathrm{Me}, \mathrm{M} / 2, \mathrm{R}_{2} \mathrm{M}^{+} .{ }^{21-23}$ The diorgano-gallium complexes derived from 2-(2hydroxyphenyl)oxazoline did not show any peak higher than the formula weight suggesting their monomeric nature. $^{22}$ 


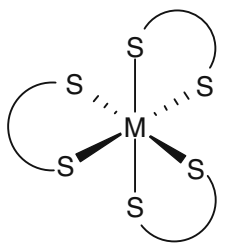<smiles>C1CS[As]2(SC1)SCCSC21SCCS1</smiles><smiles>[X]C1([S]2SCCCS2)SCCS1</smiles><smiles>[X][M]1SCCS1</smiles>

$\mathrm{M}=\mathrm{Ga}, \mathrm{In} ; \mathrm{X}=\mathrm{Cl}, \mathrm{Me}$

Scheme 3.

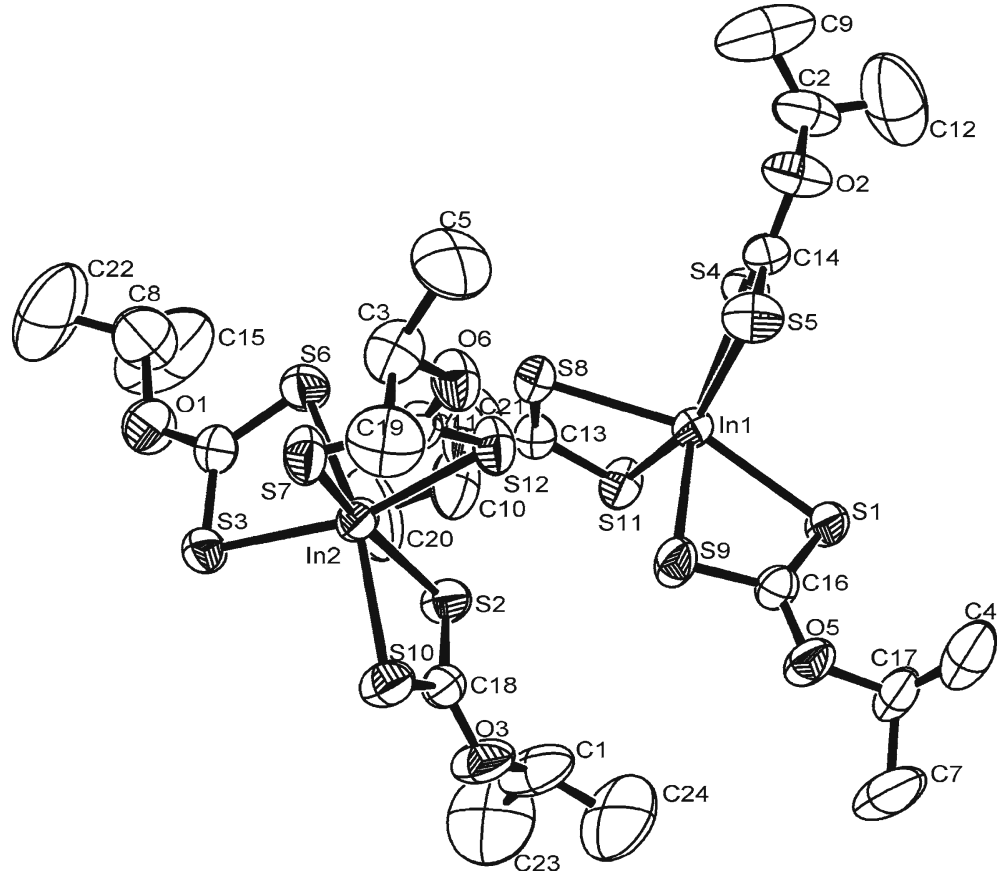

Figure 1. Crystal structure of $\left[\operatorname{In}\left(\mathrm{S}_{2} \mathrm{COPr}^{\mathrm{i}}\right)_{3}\right]$.

These complexes have been characterised by IR and NMR $\left({ }^{1} \mathrm{H},{ }^{13} \mathrm{C}\right)$ spectroscopy. The NMR spectra displayed expected resonances and peak multiplicities. The methyl-metal signals in the ${ }^{1} \mathrm{H}$ and ${ }^{13} \mathrm{C}$ NMR spectra appeared in the regions -0.40 to $+0.20 \mathrm{ppm}$ and -3.7 to $-8.3 \mathrm{ppm}$, respectively with dimethylgallium signal being more shielded.

Molecular structures of a few complexes have been established by X-ray crystallography. ${ }^{22-24}$ The structures are comprised of an oxygen-bridged dimeric unit containing five coordinate metal atoms in a highly distorted geometry defined by $\mathrm{C}_{2} \mathrm{NO}_{2}$ donor atoms. The $\mu$-oxo atoms derived from two different ligands form a central rectangular $\mathrm{M}_{2} \mathrm{O}_{2}$ core. ${ }^{22-24}$ The gallium complex, $\left[\left(\mathrm{Me}_{2} \mathrm{GaO}-\mathrm{CH}_{2}-\mathrm{dmpz}\right]_{2}\right.$ (figure 3) when recrystallised in open from dichlorom ethane, atmospheric

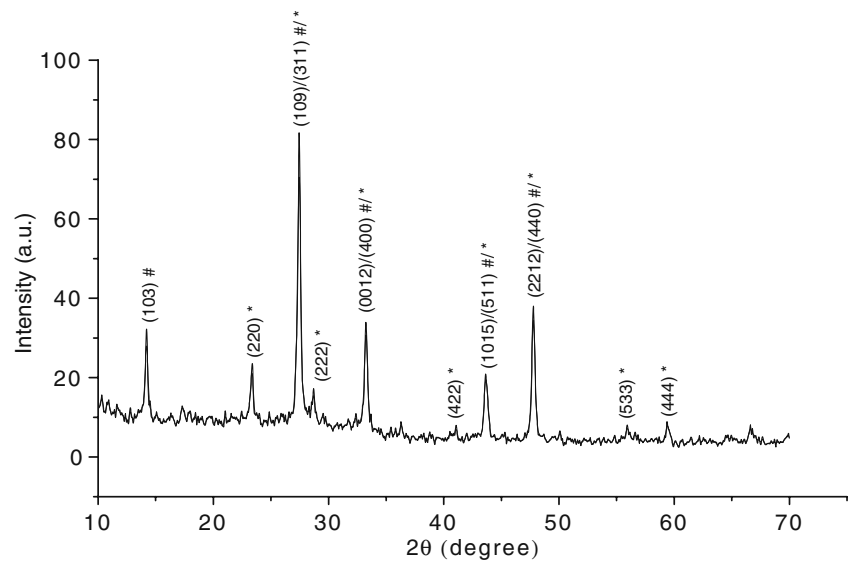

Figure 2. XRD pattern of $\beta-\mathrm{In}_{2} \mathrm{~S}_{3}$ (\# Tetragonal, * Cubic) obtained from solvolysis of $\left[\operatorname{In}\left\{\mathrm{S}_{2} \mathrm{CPh}\right\}_{3}\right]$ in HDA. 
<smiles>[O-]c1ccccn1</smiles><smiles>[O-]Cc1ccccn1</smiles><smiles>[O-]Cc1ccccn1</smiles><smiles>O=C([O-])c1ccccn1</smiles><smiles>O=C([O-])c1cnccn1</smiles><smiles></smiles><smiles>[2H][C@]1(P)COC(c2ccccc2[O-])=N1</smiles>

$\mathrm{R} / \mathrm{R}^{\prime}=\mathrm{Me} / \mathrm{Me} ; \mathrm{Me} / \mathrm{H} ; \mathrm{Et} / \mathrm{H}$

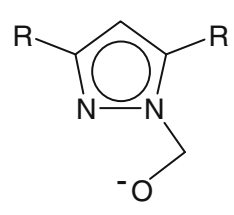

$\mathrm{R}=\mathrm{H}$ or $\mathrm{Me}$

represented as LO

Scheme 4.

$2 \mathrm{R}_{3} \mathrm{M} . \mathrm{OEt} \mathrm{t}_{2}+2 \mathrm{LOH}$

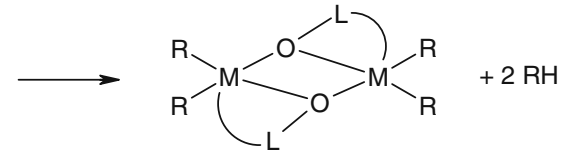

$\mathrm{M}=\mathrm{Ga}$ or In; $\mathrm{R}=\mathrm{Me}$ or $\mathrm{Et}$

Scheme 5.

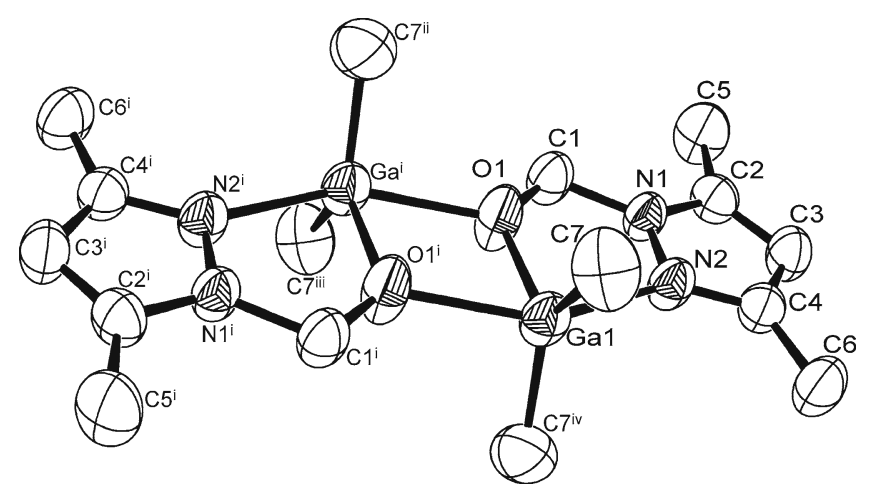

Figure 3. Crystal structure of $\left[\mathrm{Me}_{2} \mathrm{GaO}-\mathrm{CH}_{2} \mathrm{dmpz}\right]_{2}$.

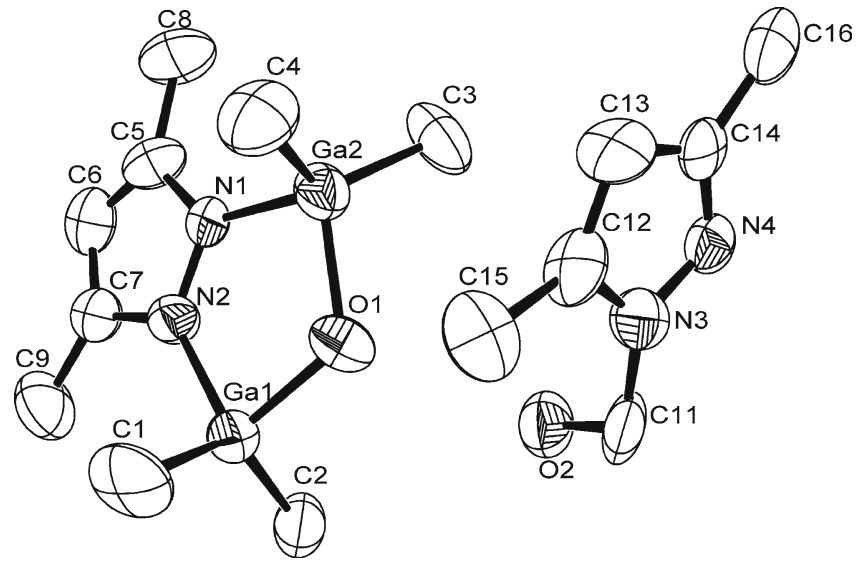

Figure 4. X-ray structure of $\left[\left\{\mathrm{Me}_{2} \mathrm{Ga}\right\}_{2}(\mu-\mathrm{OH})(\mu-\right.$ dmpz)] $\mathrm{HOCH}_{2} \mathrm{dmpz}$.

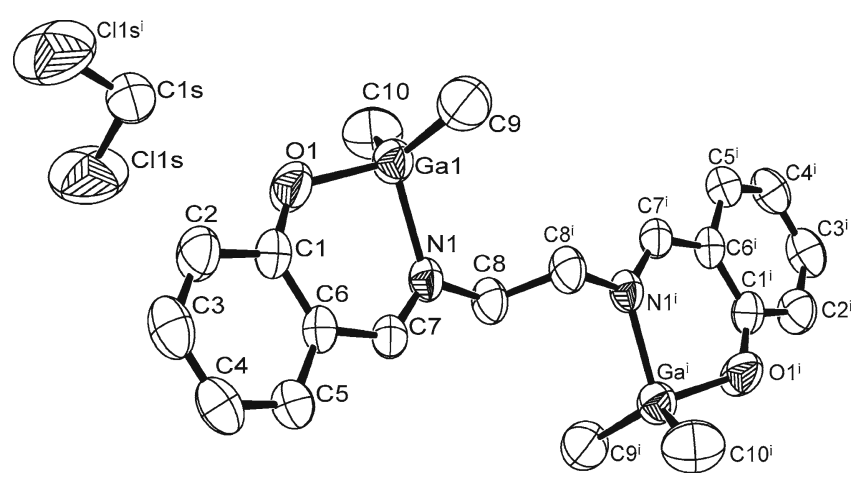

Figure 5. Crystal structure of $\left[\left(\mathrm{Me}_{2} \mathrm{Ga}\right)_{2}\left(\mathrm{O}-\left(\mathrm{C}_{6} \mathrm{H}_{4}\right) \mathrm{CH}=\right.\right.$ $\left.\left.\mathrm{N}-\mathrm{CH}_{2}-\right)_{2}\right] \cdot \mathrm{CH}_{2} \mathrm{Cl}_{2}$ grown from dichloromethane.

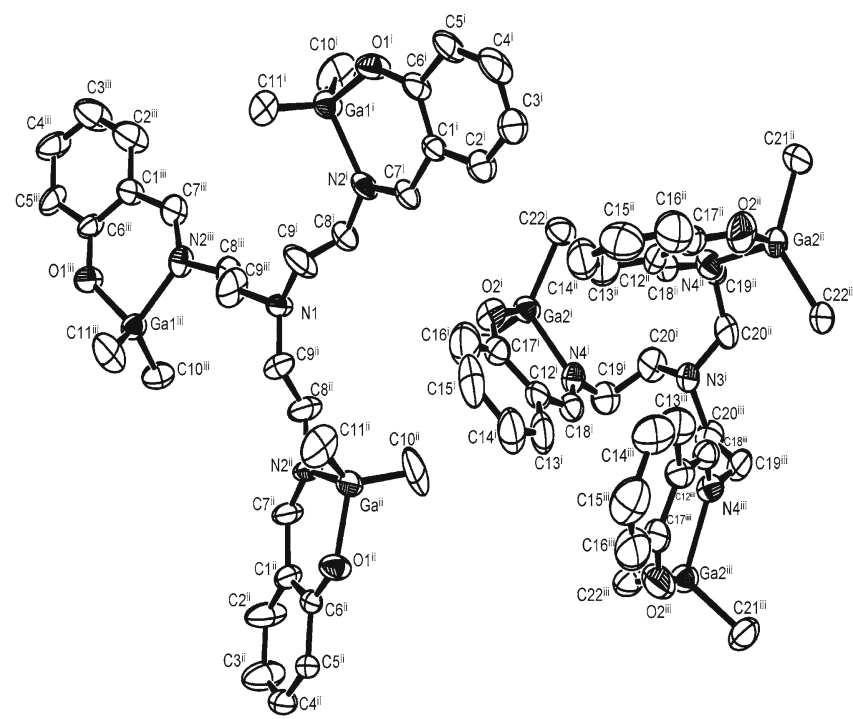

Figure 6. Crystal structure of $\left[\left(\mathrm{Me}_{2} \mathrm{GaO}-\left(\mathrm{C}_{6} \mathrm{H}_{4}\right) \mathrm{CH}=\mathrm{N}-\right.\right.$ $\left.\left.\mathrm{CH}_{2}-\mathrm{CH}_{2}-\right)_{3} \mathrm{~N}\right]$ grown from dichloromethane. 
Table 1. Excitation and emission maxima of diorgano-gallium and indium complexes.

\begin{tabular}{lcc}
\hline Compounds & Excitation $\lambda$ in nm & Emission $\lambda$ in nm \\
\hline$\left[\mathrm{Me}_{2} \mathrm{Ga}\left(\mathrm{O}_{2} \mathrm{C}-\mathrm{C}_{5} \mathrm{H}_{4} \mathrm{~N}\right)\right]_{2}$ & 257 & 368 \\
{$\left[\mathrm{Et}_{2} \mathrm{Ga}\left(\mathrm{O}_{2} \mathrm{C}-\mathrm{C}_{5} \mathrm{H}_{4} \mathrm{~N}\right)\right]_{2}$} & 252 & 369 \\
{$\left[\mathrm{Me}_{2} \mathrm{In}\left(\mathrm{O}_{2} \mathrm{C}-\mathrm{C}_{5} \mathrm{H}_{4} \mathrm{~N}\right)\right]_{2}$} & 257 & 371 \\
{$\left[\mathrm{Me}_{2} \mathrm{Ga}\left(\mathrm{O}_{2} \mathrm{C}-\mathrm{C}_{9} \mathrm{H}_{6} \mathrm{~N}\right)\right]_{2}$} & 240,308 & 362,412 \\
{$\left[\mathrm{Et}_{2} \mathrm{Ga}\left(\mathrm{O}_{2} \mathrm{C}-\mathrm{C}_{9} \mathrm{H}_{6} \mathrm{~N}\right)\right]_{2}$} & 240,310 & 364,412 \\
{$\left[\mathrm{Me}_{2} \mathrm{In}\left(\mathrm{O}_{2} \mathrm{C}-\mathrm{C}_{9} \mathrm{H}_{6} \mathrm{~N}\right)\right]_{2}$} & 240,308 & 462 \\
{$\left[\mathrm{Me}_{2} \mathrm{GaO}\left(\mathrm{C}_{6} \mathrm{H}_{4}\right) \mathrm{CH}=\mathrm{NCH}_{2}-\right]_{2}$} & 412 & 485 \\
{$\left[\mathrm{Et}_{2} \mathrm{GaO}\left(\mathrm{C}_{6} \mathrm{H}_{4}\right) \mathrm{CH}=\mathrm{NCH}-\right]_{2}$} & 335 & 485 \\
{$\left[\mathrm{Et}_{2} \mathrm{GaO}\left(\mathrm{C}_{6} \mathrm{H}_{4}\right) \mathrm{CMe}=\mathrm{NCH}_{2}-\right]_{2}$} & 355 & 455 \\
{$\left[\left(\mathrm{Me}_{2} \mathrm{GaO}-\left(\mathrm{C}_{6} \mathrm{H}_{4}\right) \mathrm{CH}=\mathrm{N}-\mathrm{CH}_{2}-\mathrm{CH}_{2}-\right)_{3} \mathrm{~N}\right]$} & 380 & 456 \\
{$\left[\left(\mathrm{Et}_{2} \mathrm{GaO}-\left(\mathrm{C}_{6} \mathrm{H}_{4}\right) \mathrm{CH}=\mathrm{N}-\mathrm{CH}_{2}-\mathrm{CH}_{2}-\right)_{3} \mathrm{~N}\right]$} & 368 & 505 \\
{$\left[\left(\mathrm{Me}_{2} \mathrm{GaO}-\left(\mathrm{C}_{6} \mathrm{H}_{3} \mathrm{OMe}-3\right) \mathrm{CH}=\mathrm{N}-\mathrm{CH}_{2}-\mathrm{CH}_{2}-\right)_{3} \mathrm{~N}\right]$} & 395 & 505 \\
{$\left[\left(\mathrm{Et}_{2} \mathrm{GaO}-\left(\mathrm{C}_{6} \mathrm{H}_{3} \mathrm{OMe}-3\right) \mathrm{CH}=\mathrm{N}-\mathrm{CH}_{2}-\mathrm{CH}_{2}-\right)_{3} \mathrm{~N}\right]$} & 400 & \\
\hline
\end{tabular}

moisture hydrolysed the complex with the cleavage of $\mathrm{N}-\mathrm{CH}_{2}$ linkage rather than $\mathrm{Ga}-\mathrm{O}$ or $\mathrm{Ga}-\mathrm{C}$ bond and a new hetero-bridged complex, $\left[\left\{\mathrm{Me}_{2} \mathrm{Ga}\right\}_{2}(\mu-\mathrm{OH})\right.$ ( $\mu$-dmpz)] (figure 4) was formed. ${ }^{24}$

The complexes devoid of ' $\mathrm{M}_{2}(\mu-\mathrm{O})_{2}$ ' core have been synthesised by employing salen type ligands. Thus, reactions of trialkylmetal etherate with salenH $\mathrm{H}_{2}$ and saltren $\mathrm{H}_{3}$ yield bi- and tri-nuclear complexes (figures 5, $6) .{ }^{25,26}$ The salen complex represents the first example of distortion isomerism as the complex could be crystallized in orthorhombic (from benzene-hexane mixture) and monoclinic (from dichloromethane) forms. In both the forms gallium atoms are five-coordinated.

\subsection{Photophysical properties}

8-Hydroxyquinolinate $(\mathrm{Ox})$ and azomethine coordinated complexes of aluminium have been employed as organic light-emitting diodes (OLEDs). ${ }^{8,27,28}$ Organometallic complexes with chelating ligands have attracted considerable attention as promising candidates for OLED applications. Several of diorgano-gallium and indium complexes described here are emissive in fluid state at room temperature (table 1). The observed absorptions and emissions in these complexes have been attributed to transitions localised on the ligands.

trans- $\left[\mathrm{PdCl}_{2}\left(\mathrm{PPh}_{3}\right)_{2}\right]+\left[\mathrm{Me}_{2} \mathrm{InOC}_{6} \mathrm{H}_{4} \mathrm{CH}=\mathrm{NCH}_{2}-\right]_{2}$

$\longrightarrow$ trans-[PdClMe $\left.\left(\mathrm{PPh}_{3}\right)_{2}\right]+$ other products.

Scheme 6.

\subsection{C-C coupling reactions}

Mononuclear organoindium complexes have been employed in cross coupling reactions of arylhalides in the presence of palladium complexes as catalyst. ${ }^{4}$ Thus binuclear salen complexes, which are akin to mononuclear derivatives, have been used in cross coupling reactions. 1-Bromonapthalene is readily methylated to 1-methylnapthalene in the presence of $\mathrm{PdCl}_{2}\left(\mathrm{PPh}_{3}\right)_{2}$ as catalyst. It has been shown that $\mathrm{PdCl}_{2}\left(\mathrm{PPh}_{3}\right)_{2}$ is converted to trans- $\mathrm{PdMeCl}\left(\mathrm{PPh}_{3}\right)_{2}$ when treated with dimethylindium complexes (scheme 6). ${ }^{25}$

\section{Conclusions}

A variety of 1, 1-dithiolate complexes of gallium and indium have been synthesized. These are discrete monomers acquiring distorted geometries due to small bite of dithio ligands. The indium dithiolate complexes are versatile molecular precursors for the preparation of $\beta-\operatorname{In}_{2} \mathrm{~S}_{3}$ nanoparticles. Diorgano-gallium and indium complexes with oxo ligands have been obtained conveniently by the reactions of $\mathrm{R}_{3} \mathrm{M} \cdot \mathrm{OEt}_{2}$ with ionic oxo ligands. The salen complexes show distortion isomerism. These complexes are emissive in solution and are employed in $\mathrm{C}-\mathrm{C}$ coupling reactions in the presence of a palladium catalyst.

\section{Acknowledgements}

Authors thank Dr. T Mukherjee, Director, Chemistry Group and Dr. D Das, Head, Chemistry Division for 
encouragement. We thank all the collaborators and co-workers whose names appear in the references.

\section{References}

1. Downs A J 1993 Chemistry of aluminium, gallium, indium and thallium (Glassgow: Blackie Academic and Professional)

2. Paver M A, Russell C A and Wright D S 1995 Comprehensive organometallic chemistry II (eds) Abel E W, Stone F G A, Wilkinson G, vol. 1, p 503

3. Schulz S 2007 Comprehensive organometallic chemistry III (editors-in-chief) Crabtree $\mathrm{R} \mathrm{H}$ and Mingos D $\mathrm{M}$ $\mathrm{P}$; (volume editor) C E Housecroft (Oxford: Elsevier) vol. 3 , chapter 3.07

4. Araki S and Hirashita T 2007 Comprehensive organometallic chemistry - III (ed) Knochel P (Oxford: Elsevier) vol 9, chapter 9.14

5. Jones A C 1997 Chem. Soc. Rev. 26101

6. Chi Y, Chou T S, Wang Y J, Huang S F, Carty A J, Scoles L, Udachin K A, Peng S M and Lee G H 2004 Organometallics 2395

7. Lazell M, O' Brien P, Otway D J and Park J 2000 J. Chem. Soc., Dalton Trans. 4479

8. Chen C H and Shi J 1998 Coord. Chem. Rev. 171161

9. Ghoshal S and Jain V K 2007 J. Chem. Sci. 119583

10. Pahari D and Jain V K 1997 Main Group Met. Chem. 20 691

11. Pahari D, Jain V K and Patel R P 1998 Main Group Met. Chem. 21261

12. Dutta D P, Jain V K, Chaudhury S and Tiekink E R T 2001 Main Group Metal Chem. 24405
13. Dutta D P, Jain V K, Knoedler A and Kaim W 2002 Polyhedron 21239

14. Prasad N, Dutta D P and Jain V K 2002 Main Group Metal Chem. 25677

15. Ghoshal S, Kushwah N P, Dutta D P and Jain V K 2005 Appl. Organomet. Chem. 191257

16. Dutta D P, Sharma G, Ghoshal S, Kushwah N P and Jain V K 2006 J. Nanosci. Nanotech. 6235

17. Ghoshal S, Jain V K, Dutta D P, Phadnis P P and Nethaji M 2006 J. Organomet. Chem. 6915838

18. Ghoshal S, Kushwah N P, Pal M K, Jain V K and Nethaji M 2008 J. Chem. Sci. 120305

19. Ghoshal S, Wadawale A and Jain V K 2008 Anal. Sci. (Japan) 24 x15

20. Kushwah N P, Dutta D P and Jain V K 2004 Indian J. Chem. 43A 535

21. Ghoshal S, Dutta D P, Kushwah N P and Jain V K 2005 Indian J. Chem. 44A 1139

22. Ghoshal S, Wadawale A P, Jain V K and Nethaji M 2007 J. Chem Res. 221

23. Pal M K, Kushwah N P, Wadawale A P, Sagoria V S, Jain V K and Tiekink E R T 2007 J. Orgamomet. Chem. 6924237

24. Pal M K, Kushwah N P, Wadawale A P and Jain V K, unpublished results

25. Kushwah N P, Pal M K, Wadawale A P and Jain V K 2009 J. Orgamomet. Chem. 6942375

26. Pal M K, Kushwah N P, Wadawale A P and Jain V K 2010 J. Chem. Res. 485

27. Friend R H, Gymer R W, Holmes A B, Burroughes J H, Marks R N, Taliani C, Bradley D D C, Dos Santos D A, Bredas J L, Lögdlund M and Salaneck W R 1999 Nature 397121

28. Brukmann M, Fite B, Batontep S and Chaumont C 2004 Chem. Mater. 164627 